\title{
Et forsvar for populærkulturen
}

- En præcisering af det populærkulturelle begreb og en kritisk læsning af Adornos syn på populærkulturen

\section{Fahrenheit 9/11, opvarmning af det kulturelle felt}

Den mest almindelige holdning til populærkulturelle produkter, som $\mathrm{fx} t \mathrm{t}$ soaps eller popmusik, illustreres dækkende af sociologen Herbert Gans, der kort sagt mener, at nydelsen af populærkultur er et symptom på uintelligent, udannet smag, som dog kan kureres ved hjælp af uddannelse (Gans 1974: 171). Mere Shakespeare og Proust i skolen vil altså kunne eliminere behovet for dårligt tv. Populærkultur placeres derved under den misforståede demokratiske tolerances vinger, hvor vi accepterer, at der også skal produceres 'kunst' til dem, der ikke ved bedre. Med sådanne venner tør man næsten ikke tage fat på fjenderne! Der er ikke langt fra sætningen "Alt tv er dårligere end en bog” til "alt tv er dårligt". Men hvis man nægter at anerkende kvalitetsforskellen på The West Wing og 2900 Happiness, og $\mathrm{i}$ stedet blindt insisterer på at evaluere The West Wing i forhold til nogle ekskluderende kriterier for god kunst, så vil man let overse den enkelte genstands kvaliteter. Kvaliteter, der måske bevæger sig uden for vores gængse kriterier for god kunst.

Jeg vil i følgende artikel forsøge et forsvar for populærkulturen via en begrebsdefinition og en kritisk læsning af modernistisk æstetisk teoris syn på populærkulturen, primært eksemplificeret ved Theodor W. Adornos kritik.

Et sådant forsvar skal ikke ses som en jubeloptimistisk 'anything goes'attitude. I mine øjne er der ufatteligt mange dårlige populærkulturelle værker, jeg ser det som en af de væsentligste årsager til at debattere populærkulturen. Det følgende er absolut ikke en total afvisning af Adornos filosofi, som hører til de mest interessante bidrag til æstetikken, men jeg vil hævde, at Adornos syn på populærkulturen stadig har så stor effekt, at vi holder os fra at engagere os i en forbedring. 
Et forsvar for populærkulturen kan måske virke som at løbe åbne døre ind, da der er en stigende accept af populærkulturelt forbrug også blandt intellektuelle, men mellem linjerne ligger stadig en teoretisk funderet stemning, hvor forbruget anses som illegitimt. F.eks. skabte det virkelig røre i det kulturelle felt, da Michael Moore i 2004 vandt verdens fineste filmkunstpris, Guldpalmen, for sin dokumentariske satire Fabrenbeit 9/11. Er der noget, som traditionelt har kunnet bygge bro mellem de politiske fløje i Frankrig, så er det behovet for at distancere sig fra den såkaldte lavkulturelle eller populære kunst, og da Michael Moore hævede trofæet i Cannes, fremstod han, med sin tunge amerikanske lave-middelklasse-fremtræden, som selve inkarnationen af populærkultur. Derved blev alt, hvad den finkulturelle franske elite forsøger at distingvere sig i forhold til, finkulturens negative referencepunkt, flyttet op på kulturfeltets trone. Den borgerlige franske avis Le Figaro og den lettere venstreorienterede Le Monde kunne da også finde fælles fodslag $i$ en fnysende utilfredshed over for Tarantino-juryens valg. Og fransk films største nulevende koryfæ, Jean-Luc Godard, var ude med hård kritik, selv om han stolt proklamerede, at han ikke havde set filmen. ${ }^{1}$

Franskmændene frygtede, at det subjektivt klippede portræt af George W. Bush ville skade filmfestivalen, da et valg af en så direkte politisk engageret amerikansk dokumentar kunne true festivalens status som den ypperste med hensyn til det kunstneriske. Her, seks år efter, virker det lidt drastisk at frygte Cannes-festivalens fald fra tinderne, men reaktionen er stadig interessant. Jean-Luc Godard, der ellers selv ofte har ytret sig på den politiske venstrefløj og i 2004 sikkert også gerne så en ny mand i Det Hvide Hus, anklagede Michael Moore for kun at være "halvt intelligent" og sagde, at han med sit direkte udspil gjorde mere skade end gavn. Dermed mente Godard, at Moore ikke var herre over sit eget materiale, og at sådan et direkte kritisk udspil lettere kan misbruges, forvrænges eller blankt afvises, end en mere subtil formmæssig kritik.

Der er to dele af de franske angreb, som er interessante. For det første frygtede de det populærkulturelle stempel i sig selv, for det andet korresponderede Godards kritikbrokker med Adornos æstetik, fx Adornosætningen: "Hvis kunsten vil protestere direkte mod det tætte net, så bliver den fanget i det for alvor" (Adorno 1998: 236). Tanken er, at god kunst er den kunst, som giver en kritik af samfundet og derved byder på et alternativ, men ifølge Godard ikke på den måde, som Moore kritiserer. Kritikken bør komme gennem kunstværkets form, for kun gennem formen kan den 
sikre sin autonomi. Populærkulturen, her en satirisk politisk dokumentar, formår ifølge Godard ikke at bevare denne autonomi, men hvad den tydeligvis heller ikke har formået, er at frigøre sig fra modernistisk æstetikteoretisk undertrykkelse. Et forsvar for populærkulturen må derfor gå gennem en kritisk læsning af den undertrykkende teori.

\section{Populærkultur, en kamp om klassifikation}

Når man vil beskæftige sig med et så diffust fænomen som populærkulturen, kræver det først en nærmere indkredsning af begrebet. Popularkultur har udviklet sig til et samlende begreb for en hel række termer (massekultur, lavkultur etc.), hvis konnotationer alle hænger ved. Der ligger allerede en kamp i valget af ord og definitioner, så jeg vil indledende rode lidt op i dette samlebegreb med henblik på at skabe klarhed om artiklens genstand.

Begreberne popularkultur og popularkunst er meget åbne begreber. De er mest af alt defineret negativt, som noget man forsøger at distancere sig fra, hvilket også er den funktion, de oftest gives i æstetikteorien. I hverdagssproget defineres populærkunst som en bastardgenre, sammensat af alt det, vi ikke kategoriserer som 'rigtig' kunst, men derimod som ukritisk underholdning for almindelige folk. Den er knyttet til teknologisk reproduktion, og normativt hævdes det, at den støtter op om status quo.

Som Pierre Bourdieu viste i Distinktionen. En sociologisk kritik af dommekraften og Michael Moore i 2004 viste i praksis, er grænserne mellem de forskellige klassificeringer relationelle, og hvad der kategoriseres som fin- eller populærkulturelt omskifteligt. Det har til gengæld vist sig sikkert, at etiketten populærkultur ikke får lov at flytte med op i det gode selskab.

Begrebet popularkunst er i selve sin konstruktion fyldt med paradoksale konnotationer, da populærkulturen traditionelt slet ikke forbindes med kunst. Den ses nærmere som en kapitalistisk parasit, der suger næring fra den 'rigtige' kunst/kultur, for at skabe en vare for almindelige mennesker. Den amerikanske kunstkritiker Clement Greenberg benytter sig af det tyske ord Kitsch ${ }^{2}$ for al "populær, kommerciel kunst" (Greenberg 1994: 247), der ikke formår at leve op til hans avantgardistiske krav om, at kunsten skal være grænsesprængende. Kitsch, som fx Hollywoodfilm og Tin Pan Alley-hits, beskrives som grådige vampyrer, der suger livgivende blod fra ægte kunst for at skabe en "erstatningskultur, beregnet for dem som, selv om de er ufølsomme over for den ægte kulturs værdier, ikke desto mindre er sultne efter den adspredelse som kun en eller anden form for 
kultur kan give" (Greenberg 1994: 247). Greenbergs, og som vi senere skal se også Adornos, kritik af populærkulturen går fundamentalt set på dens varekarakter, hvilket åbenbart gør den ugyldig i æstetiske sammenhænge.

Populærkulturen har sine rødder i almindelige menneskers folkekultur, men disse bånd blev skåret over i forbindelse med de teknologiske fremskridt i det moderne (Greenberg 1994: 247) Selv om den romantisk nostalgiske opfattelse af folkekulturen som noget mere autentisk må stå som en skrøbelig antagelse, er der ingen tvivl om, at populærkulturen lever med negative konnotationer af en kultur, der har ødelagt noget, som var bedre. Det må igen knyttes til tanken om populærkulturens varekarakter, for finkulturen distancerede sig også fra folkekulturen. Tanken må være, at det aktive dilettantteater, trods sine mangler, havde en nærhed og en brugsværdi, som nu elimineres af X Factor. Populærkulturen får således på en gang overført folkekulturens identitet som udannet, og må samtidig stå som den moderne fremmedgjorte kultur, der har spoleret folkekulturens auratiske egenskaber.

Populærkulturen er således et moderne begreb, som knytter sig til den teknologiske udvikling. Hvor man tidligere havde et skel mellem fin- og folkelig kultur, taler man efter den industrielle revolution og storbyens opkomst mere om finkultur over for massekultur. Begreberne masse- og populærkultur er umiskendeligt viklet ind i hinanden, og kan generelt substituere hinanden, men hvor populærkultur antyder en forbindelse til folkekulturen, træder massekultur frem og understreger sin uadskillelige sammenhæng med det moderne. Massekunsten er den kunst, som er fremstillet og distribueret ved masseteknologi med henblik på det størst mulige publikum (Carroll 1998: 4): Massekulturen er popularkulturen $i$ den tekniske reproducerbarbeds tidsalder. Hvorfor så ikke blot bruge begrebet 'massekultur'? Det er også, hvad mange af populærkulturens fortalere har gjort: Walter Benjamin, Marshall McLuhan og Noël Carroll er alle teknologisk fokuserede. Problemet er, at den enorme fokus på teknologi og brugen af begrebet masse har mange negative konnotationer. Man behøver ikke bevæge sig over i en Baudrillard'sk simulakra-terminologi for at se, at der ikke længere er nogen grund til at tale om teknologien som noget, der er specifikt knyttet til én kultur- eller kunstform frem for andre. Adorno gjorde en pointe ud af at erstatte massekultur med begrebet kulturindustri, på det tidspunkt, for at tydeliggøre at det ikke var en kultur, som var opstået af sig selv, men en standardiseret kulturform, der var blevet tvunget ned over hovedet på massen af kapitalistisk industri (Adorno 1972: 31). I dag er begrebet mas- 
sekultur så betændt med denne tydeliggjorte forbindelse til noget ufrit, at der kan være en emanciperende pointe $\mathrm{i}$ at benytte sig af populærkultur. Begrebet masse har klangen af et udifferentieret umenneskeligt aggregat (Friberg 2003: 116). Hvorimod begrebet populærkultur har den fordel, at det har udviklet konnotationen af noget mere tilgengængeligt og derfor bedre tilgodeser muligheden for subjektive (og sanselige) erfaringer. Desuden har populærkulturen den banale fordel at have fået en positiv klang pga. ordet populær.

Første skridt $\mathrm{i}$ et forsvar for populærkulturen må være at bryde klassificeringens negativt stigmatiserende logik (Bourdieu 1995: 232). At gå ind i kampen om retten til at navngive begreberne, som fx Susan Sontag gjorde med netop begrebet kitsch i sin Notes on Camp, er med til at skabe en ny sensibilitet, en ny bevidsthed om de fænomener, som befinder sig inden for kategoriseringen. Pointen i et forsvar for populærkulturen er, at man skal begynde at se på enkeltfænomenerne på deres egne præmisser og ikke ud fra ekskluderende forestillinger om et kunstbegreb. Men for at nå så langt, må man i teoretiske sammenhænge acceptere, at hele det populærkulturelle felt med film, tv, popmusik etc. bliver sat under et navn (Bourdieu 1995: 240). Gør man ikke dette, vil hver enkelt kæmpe sig ud af undertrykkelsen selv og aldrig skabe en succes af mere fundamental æstetikteoretisk karakter.

\section{Populærkultur, fem definitioner}

Efter den ovenstående indkredsning af det populærkulturelle samlebegreb kan vi opstille fem definitioner, i sin ordlyd lånt fra musikforskeren Karin Petersens artikel Popmodernisme (2000):

Normativ definition: Populærkultur og -kunst er dårlig, ment for dem der ikke ved bedre.

Negativ definition: Populærkultur og -kunst er det som ikke er 'ægte kultur'.

Sociologisk definition: Populærkultur har evnen til at skabe gruppedannelse, hvor individet, det klart definerede subjekt, let kan forsvinde til fordel for en gruppeidentitet.

Teknologisk definition: Populærkunst og -kultur er noget, der opstår og udvikler sig i takt med det moderne samfunds teknologiske udviklinger. Bag disse fire definitioners negative klang lurer en femte definition, som Karin Petersen kalder: 
Typologisk: Populærkultur og -kunst er underholdning fremstillet med henblik på profit. Den er først og fremmest en vare.

Jeg vil, som Karin Petersen, hævde, at denne varekarakter sætter præmisserne for populærkulturens normative og negative definitioner. Langt hen ad vejen er den teknologiske definition også viklet ind i denne varekarakter, for i vores omtale af populærkulturens relation til produktionsapparatet er der ofte en underforstået fordømmelse af dette produktionsapparat. Adorno er den teoretiker, der om nogen etablerer dette fokus på populærkulturens varekarakter. Og det er i Adornos skygge, det populærkulturelle begrebs negative klang opstår (Petersen 2000). Adornos udfald mod populærkulturen er harske. Hans kritik af kulturindustrien ligger i forlængelse af en større civilisationskritik, ${ }^{3}$ hvor den ses som et eksempel på den sene kapitalismes vanvid, hvor kunst og kultur er blevet standardiseret som vare med henblik på salg. Jeg vil i det følgende gå ind i Adornos konkrete kritik af populærkulturen gennem en kritisk læsning af de to tekststykker Om kulturindustrien (Adorno 1972) og On Popular Music (Adorno 1990).

\section{Adornos syn på populærkulturen, en kritisk fremstilling}

Adorno har ikke meget til overs for populærkulturen. Han gør en pointe ud af at tydeliggøre relationen til det kapitalistiske produktionsapparat og taler derfor om kulturindustrien. Derved påpeger han, at den er en ufri kultur, en vare påtvunget masserne. "Kunden er ikke - som kulturindustrien vil have os til at tro - konge, han er ikke industriens subjekt, men dens objekt" (Adorno 1972: 31). Industrien spinder sit kvælende profitmotiverede net over de åndelige frembringelser. Den angriber både kunstværket og subjektets autonomi, som begge gøres til blotte objekter i byttelogikkens konsum-konsument kalkule. Adorno viser ikke megen tiltro til den gennemsnitlige kulturforbruger: I hans On Popular Music mener han at kunne fastslå, at de fleste mennesker slet ikke forstår sig på musik. Hvis de gjorde, ville de ikke acceptere kulturindustriens standardiserede produkter (Adorno 1990: 311), da koncentreret lytning afslører dem som uudholdelige. Og i Om kulturindustrien skriver han: "Sætningen: verden vil bedrages, er blevet mere sand end den vel nogen sinde har været ment" (Adorno 1972: 35). Massen undskyldes dog med det lidet flatterende, at de er ofre for omstændigheder i samfundet. De har ikke forudsætningerne for at 
nyde kunst, og som hos Herbert Gans er det et spørgsmål om, at de har for lidt dannelse og tid til fordybelse. Gennem rationaliseret arbejdsdeling er massen vænnet til gentagelsen, ligesom hos Chaplin i Modern Times er den fragmenterede hverdag blevet en del af vores habitus, og når vi kommer hjem, kan vi ikke længere klare andet end en substituerende stimulans for æate kunst (Adorno 1990: 311). Denne underholdning står i undertrykkelsens tjeneste. Popmusikken bliver skabt over samme skema med små variationer, så forbrugeren på en gang bliver fritaget for anstrengelse og samtidig oplever noget nyt. Som Greenberg karakteriserer kitsch som en masseproduceret vare, der "skifter med moden, men altid [er] det samme" (Greenberg: 248), beskriver Adorno variationerne i populærkulturen som lige så uændrede "som profitmotivet selv, efter at den har fået herredømme over kulturen” (Adorno 1972: 32). Ved at gå bag om efterspørgslen, bag om producentens 'jeg giver blot de unge dét, de vil have'-undskyldning, og skyde efter nogle bagvedliggende kultur- og klassestrukturer, lægges der en ideologikritisk tråd ud, som blandt andre Roland Barthes senere tager op i sin behandling af borgerskabets selvbekræftelse gennem massemedierne (Barthes 1969).

Adornos pessimistiske syn på subjektets handlemuligheder virker voldsomt for en nutidig læser. Han har ingen tro på, at de populærkulturelle 'kunstnere', produkter og konsumenter kan handle på egen hånd inden for kulturindustriens mekanismer og dermed indefra skabe noget positivt. På den anden side kan man ikke komme uden om, at hans beskrivelser af disse kapitalistiske mekanismer ofte er knivskarpe. Hans dissekerende analyse af Tin Pan Alley-produktionen som industriens "fastfrysning af standarder" (Adorno 1990: 306), fastholdelsen af et simpelt skema, der virker og appellerer til laveste fællesnæver og stadig gennem pseudoindividualisering fastholder illusioner om frihed, vækker stadig genklang i dag. De to pseudoindividualiseringsmekanismer er Stjernesystemet, der holder publikum fast i troen på et klart defineret subjekt bag værkerne, og Labelling, som gennem marketingsstrategiske genredistinktioner leder publikums opmærksom hen på de sociale identitetsdannende aspekter. Så en uvidende ungdomskultur bruger al sin opmærksomhed på at distingvere sig gennem dyrkelse af Britney Spears vs. Lady Gaga og derved sløres sandheden: At de er ens (Adorno 1990: 307-309). Sådanne distraktioner er det mål-rationelle samfunds røgslør, og skaber på en gang både behovet og produktet. 
Problemet opstår, hvis man slutter direkte fra de korrekte elementer i Adornos negative beskrivelse af det kapitalistiske apparat, til et fuldstændigt stagneret kulturliv, hvor alt, "der kunne bevirke forandring [...] er fuldstændig lukket ude” (Adorno 1972: 31). Adornos tankegang glider over i en dualistisk terminologi, som kreerer et ensidigt fjendebillede, hvor kulturindustrien kommer til at dække hele det populærkulturelle begreb. En identitetstvang, som man ellers skulle tro, at Adorno ville være opmærksom på. Hans harske udtalelser om kulturindustrien skal ses ud fra én klar tanke om, hvad kultur og kunst bor være: nemlig fastholdelsen af en utopisk forestilling om ideen om et bedre liv gennem kritik (Adorno 1972: 36). Hvis kunst og kultur skal være mere end blot "en frase", må den påtage sig sit ansvar og ikke tilpasse sig industriens ideologi (Adorno 1972: 37). Tilpasser den sig, slår den over i "anti-oplysning [...] et middel til at lægge bevidstheden i lænker” (Adorno 1972: 39) - en katarsis for masserne, hvor vi kan vælge mellem at forsvinde $\mathrm{i}$ individundertrykkende gruppeidentitet eller fælde en resigneret tåre og lade stå til (Adorno 1990: 311-312).

I sit ensidige fokus på populærkulturens varekarakter gør Adorno sig til et eksempel på det Umberto Eco kalder en 'apokalyptisk intellektuel' (Eco 1994), som sætter en elitær forståelse af højkultur over for massens svælgen i en massekultur, der fremstilles som anti-kultur. Adorno fokuserer for ensidigt på populærkulturens varekarakter og for lidt på konkrete værkers reception og brug, dertil kan man lægge en dystopisk opfattelse af subjektets muligheder over for en kulturindustri, der, ifølge Adorno, på egen hånd "forhindrer skabelsen af autonome, selvstændige, bevidst vurderende og besluttende individer" (Adorno 1972: 39).

Neo-pragmatisten Richard Shusterman pointerer, at kritikken af populærkultur ofte blander socio-politiske og æstetiske kriterier sammen (Shusterman 1992: 167-201). Et eksempel på dette er, når Adorno slutter fra en beskrivelse af en række sociale patologier, til nogle kriterier for kunst og dermed til en fordømmelse af dén (populær)kunst, som ikke lever op til disse. Adorno lægger vægt på standardiseringen, profitten, varekarakteren og på, at en overfladisk uægte kultur er tvunget ned over hovedet og fordummer en allerede fordummet forbruger. Det er vanskeligt at modsætte sig ønsket om mindre udbytning og fordummelse, men Adornos utopiske ønsker berettiger ikke en fuldstændig fordømmelse af hele populærkulturen.

Allerede i Adornos antagelse af populærkulturen som overfladisk og uanstrengt ligger der et par skjulte dualistiske forestillinger. Det er en prio- 
ritering af det mentale over det somatiske. Han glemmer, at populærkulturen ofte krcver fysisk deltagelse, og samtidig glemmer han, at det kræver mod og overvindelse at træde ud på dansegulvet. Det er samtidig en underkendelse af flygtighed over for permanens, men blot fordi noget ikke initierer en varig verdensomvæltende kritik, kan det stadig byde på gyldige æstetiske erfaringer. Shusterman pointerer, at når Adorno siger at "i en falsk verden er al hedone falsk" (Shusterman 1992: 182), så er det en valuering af permanens over flygtighed, som lugter langt væk af teologisk tankegods - en prioritering af et kritisk fremtidsprojekt frem for forsoning med verden her og nu. Men, siger Shusterman: "Noget der kun eksisterer for en tid eksisterer ikke desto mindre, og en midlertidig tilfredsstillelse er stadig en tilfredsstillelse" (Shusterman 1992: 179). At underkende kunst, som beskæftiger sig med banale hverdagserfaringer, som ulykkelig kærlighed, fattigdom og manglende seksuel tilfredsstillelse, er en underkendelse af denne verden til fordel for en utopisk fremtid.

Argumentet, at populærkultur skulle være mere påtvunget end finkultur, er uholdbart. Vi er altid situeret i en kontekst, og i den forstand er en hvilken som helst kultur i en eller anden grad påtvunget. Vi bliver uomtvisteligt påtvunget mere finkultur end populærkultur: Homer udgør en større del af vores uddannelsespensum end Michael Moore. Om man kalder en kultur tilbudt eller påtvunget er i høj grad et spørgsmål om, hvilken værdi man tillægger genstanden. Profitanklagen lider af samme argumentsvaghed. Finkulturelle produkter er som hovedregel skabt med henblik på salg. Men hvad er det så, Adorno mener? Adorno kritiserer kulturindustrien for dens standardisering. Ikke teknologien som sådan, selv Beckett trykkes i store oplag. Det handler om selve genstandens form. Adorno frygter, at man pga. profitmotivet vil indrette produktionsapparatet til at ramme et stort marked, og dette vil hindre den frihed $i$ formen, som Adorno anser som vigtig. Kritikken af kulturindustrien viser sig således som en æstetisk kritik, da skrækscenariet er at masseproduktion skal udrydde det autonome kunstnersubjekt. Den primære kritik af populærkulturen er altså baseret på et ønske om at bevare en form for autonomi og muligheden for kompleks beskæftigelse med 'nye' former, og dette er ikke muligt, når kunsten indgår i en konsum-konsument-byttelogik. Adorno påstår hermed, at det er umuligt at skabe anderledes, progressiv, og derved kritisk kunst, så længe kunstneren skal tage hensyn til markedet. Det er en fejlslutning fra en kritik af, hvordan produktionsapparatet ofte fungerer, til en afvisning af, at der kan skabes originale værker inden for disse 
rammer, samt en underkendelse af en række ukritiske æstetiske erfaringer, som Adorno ikke tilskriver nogen værdi.

Adornos påstande her bunder nok i en gammeldags elitær undervurdering af det populærkulturelle publikum, men som de to venstreorienterede politiske tænkere Hardt og Negri pointerer i Empire, kan man ikke længere tale i så simple enheder som folk, masse etc. (Hardt 2001: 344). Adorno glemmer i sin overbevisning om et størknet kulturliv, at kunstgenstanden bliver sat i spil på et marked med en mangfoldighed af forskellige habitus og smagspræferencer. En Hollywood-film som Top Gun kan både nydes straight på flyverakademiet og som queer kultfilm i homoseksuelle miljøer. Og unge feminister kan godt nyde Dallas uden at blive spundet ind i herredømme-forhold. Samtidig må det siges, at hele tanken om en relativ kunstnerisk autonomi som nødvendigt fundament for god kunst lyder som en romantisk genitanke i slør. Men selv hvis vi kræver, at kunstneren skal bevare sin integritet over for sig selv, skabe sin egen base for at skabe rigtig kunst, så kan man med Benjamin pointere, at de gamle skel producent og publikum er blevet nedbrudt med de nye produktionsforhold (Benjamin 1998: 47). Kunstneren kan så at sige godt producere mod markedet og samtidig bevare sin integritet, for han producerer til sig selv.

\section{Autonomi, form og kritisk potentiale}

Adornos kritik af populærkultur bunder groft sagt i dens manglende kritiske potentiale. Hos Adorno skal kunsten redde os fra den verden, han beskrev i Oplysningens Dialektik. Kant etablerede det æstetiske som en autonom sfære, uafhængig af både naturen og fornuften, og definerede smagsdommen som interesseløs. Adorno har fat i en mere historisk betinget autonomi. Kunstværket er på en gang autonomt, en selvstændig sfære, der ved sit frie valg af form kan unddrage sig den instrumentelle fornuft, og samtidig et samfundsmæssigt faktum. Det er derfor, at formen bliver så vigtig hos Adorno, det er derfor han frygter popmusikkens hitskema og derfor Jean-Luc Godard i Cannes kaldte Moore for kun "halvt intelligent". Adorno har en meget klar funktion for kunsten, og det er, at den gennem sin funktionsløshed, sin evne til at afvise den instrumentelle fornuft, skal pege på det ikke-identiske, det som ligger uden for vores teknisk-instrumentelle verdensbillede. Igennem kunstens pegen på det som undslår sig vores beherskelsestrang, kan vi ane muligheden af en mere emfatisk sandhed. En sandhed, hvor verden ikke blot er identisk med sit begreb. 
Formen bliver det helt centrale hos Adorno, for det er gennem formen, at man "markerer kunstens strenge antitese fra det empiriske liv" (Adorno 1998: 249). Hvis kunstværket skal være i stand til at pege mod noget andet end de eksisterende samfundsformer, må det ikke, som Godard anklagede Moore for at gøre, blot udforme en direkte kritik, for "det er netop i kraft af sin distance til empirien at kunsten tager stilling" (Adorno 1998: 255). Michel Moore lider ifølge Godard og Adorno, af "den forestilling som er udbredt hos mindre reflekterede kunstnere, om at man kan vælge materialet" (Adorno 1998: 260), hvilket er problematisk da de så i "den grad ignorerer materialets tvang” (Adorno 1998: 260). I Adornos æstetik hyldes formeksperimentet: jo mere kunsten løsner sig fra motiver, desto tydeligere taler den et ikke-begrebsligt sprog og kan stumt pege mod det ikkeidentiske, det mulige andet. Filosofferne Shusterman og Simon Critchley (Critchley 2000) har begge, hver for sig, vist formeksperimenter og kritisk potentiale i hiphop og triphop, og det er i øvrigt værd at overveje om den mest effektive kritik de senere år ikke er kommet fra populærkulturelle værker, fx The West Wing, der bruger det kendte tv-serie format til at vise nye muligheder, fx en farvet præsident. Eller som Michael Moore, der i en overdrivelse af den kendte dokumentarform formår at komme i dialog med sit publikum ved brug af den latter, som Benjamin i en sidebemærkning noterer som det bedste udgangspunkt for tænkning (Benjamin 1998: 59). Selv med påvisningen af former for kritisk potentiale i populærkulturen, er det stadig relevant, som kulturteoretikeren Andreas Huyssen gør det, at påpege, at tiden er løbet fra at måle kunstnerisk aktivitet ud fra kun ét kriterium (Huyssen 1995). Adornos kompromisløse kritik af den standardiserede populærkultur gør dette, og denne kritik ligger stadig mellem linjerne i samfundets syn på populærkulturen, fx den franske reaktion over for Moore. Pointen er ikke at ønske kritikken helt ud af kunsten. Vi skal blot hele tiden være opmærksomme på, at vi ikke overfører kritisk potentiale via formeksperimenter som altdominerende evalueringskriterium til populærkulturen, men i stedet giver plads til æstetiske erfaringer, som vi hidtil har overset og forbedringer af disse. 


\section{Noter}

1 Thomas Hansen har i Berlingske Tidende 26. maj 2004 sammenfattet forskellige franske avisers kritik. Citaterne fra Godard senere i artiklen stammer fra pressekonferencer og interviews i Cannes - de optrådte også i tv fx CBC, fredag 21. maj 2004.

2 Kitsch oversættes til dansk med blandt andet: Forlorent makværk, juks, uægte, kunstnerisk værdiløs ting, simili, fidusmaleri, forsimpling, forfladigelse.

3 For en fuld forståelse af grundlaget for Adornos kritik af kulturindustrien bør man læse Horkheimer/Adorno: Oplysningens Dialektik, Gyldendal, 1995.

\section{Litteratur}

Adorno, Theodor W.(1998): Estetisk Teori, Gyldendal Norsk Forlag.

Adorno, Theodor W.(1995): "Det naturskønne” i Jørgen Dehs (red.), Estetiske teorier, Odense: Universitetsforlag.

Adorno: Theodor W. (1983): Den ny musiks filosofi, Kbh: Tiderne Skifter.

Adorno, Theodor W. (1972): “Om kulturindustrien” i Theodor W. Adorno, Kritiske modeller, Kbh: Rhodos, 1972.

Adorno, Theodor W (1990): “On Popular Music" i Simon Frith og Andrew Goodwin (red.), On Records, Rock, Pop, and the Written Word, London: Routledge.

Barthes, Roland (1969): Mytologier, Kbh.: Rhodos.

Benjamin, Walter (1994): "Kunstværket i dets tekniske reproducerbarheds tidsalder", K®K, 77, Medusa.

Benjamin, Walter (1998): “Skribenten som producent” i Walter Benjamin, Kulturkritiske essays, Kbh.: Nordisk Forlag.

Bourdieu, Pierre (1995): Distinktionen. En sociologisk kritik af dommekraften, Kbh.: Det lille forlag.

Carroll, Noël (1998): A Philosophy of Mass Art, Oxford: Clarendon.

Critchtley, Simon (2000): "Sounding Desire - On Tricky" i Birgit Bærøe (red.), Deterritorializations. Art and Aesthetics in the 90s, Oslo: Spartacus Forlag AS.

Eco, Umberto (1994): "Apocalyptic and Integrated Intellectuals: Mass Communication and Theories of Mass Culture" i Robert Lumley (red.), Apocalypse postponed, Bloomington: Indiana University Press.

Friberg, Carsten (2003): Estetiske erfaringer. Ph.d.-afhandling, Københavns Universitet. Gans, Herbert (1974): Popular Culture and High Culture: An Analysis and Evaluation of Taste, New York: Basic Books.

Greenberg, Clement (1994): “Avantgarde og kitsch" i Frans Gregersen og Simo Køppe (red.), Idehistorie 2, Kbh: Forlaget Amanda.

Hardt, Michael og Antonio Negri (2001): Empire, Cambridge: Harvard University Press. Horkheimer, Max \& Adorno. T.W (1995): Oplysningens Dialektik, Kbh: Gyldendal.

Huyssen, Andreas (1995): "Memories of Utopia" i Andreas Huyssen, Twilight Memories, 
New York: Routledge.

Petersen, Karin (2000): "Popmodernisme. Æstetiske overvindelser i populærmusikken” i Morten Kyndrup (red.), Æstetisk, teori?, Århus: Aarhus University Press.

Shusterman, Richard (1992): Pragmatist Aesthetics - Living Beauty, Rethinking Art, Cambridge Massachusetts: Blackwell.

Sontag, Susan (1992): "Notes on Camp" i Susan Sontag, Against Interpretation, London: Vintage. 
